\title{
STRATEGI PENGEMBANGAN EKOWISATA HUTAN BAMBU DI KABUPATEN LUMAJANG
}

\author{
Maulida Lujeng Sri Rahayu*, Wahyu Hidayat, Yunan Syaifulloh \\ Program Studi Ekonomi Pembangunan, Fkaultas Eknomi dan Bisnis, Universitas Muhammadiyah \\ Malang, Jl.Raya Tlogomas No.246 Malang, Indonesia \\ * Corresponding author: maulida71@gmail.com
}

\begin{tabular}{ll}
\hline Artikel Info & Abstract \\
\cline { 2 - 3 } Article history: & This research aims to study the Strategy for Developing \\
Received 20 August 2019 & Bamboo Forest Ecotourism in Lumajang Regency. This type \\
Revised 15 December 2019 & of research is a type of qualitative descriptive research. The \\
Accepted 5 January 2020 & source of the data used in this study is primary data. Primary \\
Available online 15 February & data is the main research data obtained by researchers at the \\
2020 & time researchers in the field. Primary data in this study \\
& consisted of interviews. This research was conducted in the \\
Keyword: Ecoutourism; & Bamboo Forest tourism area in Lumajang Regency. Analysis \\
Tourism & of the data used is the analysis of SWOT (Strengths, \\
& Weaknesses, Opportunity, Threats). The results showed that \\
& the Bamboo Forest Ecotourism in Lumajang District produced \\
several strategies for developing the Bamboo Forest Ecotourism \\
that included improving management systems to encourage \\
community empowerment, collaborate with parties or travel \\
agents, increase potential, improve infrastructure, and carry \\
out promotions. Bamboo Forest has adequate facilities to carry \\
out various activities. Ecotourism management is expected to \\
add supporting infrastructure of Bamboo Forest ecotourism \\
and maintain the ecotourism sustainability.
\end{tabular}

\section{PENDAHULUAN}

Pengembangan pariwisata alternatif berkelanjutan khususnya ekowisata merupakan pembangunan yang mendukung pelestarian ekologi dan pemberian manfaat yang layak secara ekonomi dan adil secara etika dan sosial terhadap masyarakat. Ekowisata juga dapat dikatakan sebagai perjalanan wisata menuju suatu lingkungan (baik yang alami maupun buatan), juga termasukke dalam budaya yang bersifat informatif dan partisipatif bertujuan untuk menjamin kelestarian alam maupun sosial budaya. Sehingga ekowisata sendiripun berfokus pada tiga hal mendasar yakni : dapat memberikan manfaat dalam ekonomi, keberlanjutan dalam ekologi atau alam, serta secara psikologi bisa diterima dalam kehidupan sosial masyarakat. Jadi, kegiatan ekowisata dengan secara langsung akan memberikan akses kepada seluruh masyarakat untuk dapat menikmati, mengetahui, dan melihat pengalaman alam, intelektual dan budaya masyarakat lokal (Oktaviana, 2016). Pengaruh hiburan dan sarana pendukung yang tidak signifikan menunjukan bahwa kedua variabel tersebut bukan menjadi penentu utama kepuasan pengunjung sebagai representasi sebagai kinerja pariwisata tetapi pelayanan dan kondisi alam lebih berpengaruh secara signifikan terhadap kinerja ekowisata din kabupaten Malang (Boedirachminarni, 2017). Provinsi Jawa Timur memiliki potensi obyek wisata yang besar dengan pola pengembangan berdasarkan pariwisata yang dapat memberikan pertumbuhan ekonomi terhadap provinsi Jawa Timur . Pariwisata minat khusus (ekowisata) merupakan pergeseran dari arah konsep kepariwisataan, menjadikannegara dengan potensi alamnya luar biasa 
memiliki peluang yang besar (Kumala, Soelistyo, \& Nuraini, 2017). Pengembangan UMKM berbasis industry kreatif dengan melihat kekuatan, kelemahan, ancaman dan peluang di sector kuliner, kerajinan, fashion, musik, dan permainan interaktif di Kota Malang, serta untuk menentukan strategi dan strategi utama untuk pengembangan UMKM berbasis industry kreatif di sector kuliner, kerjinan, fashion, musik, dan permainan interaktif di Kota Malang (Ananda \& Susilowati, 2017). Manurut (Di \& Denpasar, 2017) Sektor basis kesempatan kerja di Kota Denpasar tertinggi ialah sektor angkutan, pergudangan dan komunikasi, strategi mengarah pada memepertahankan faktor kekuatan dan peluang kota denpasar dengan strategi prioritas ialah kebijakan pemerintah untuk memberdayakan masyarakat yang kreatif. Strategi perencanaan dan pengembangan yang dapat diterapkan pada objek wisata pantai Duta Probolinggo (Choridatul, Wahyu, \& Sudarti, 2018).

Kegiatan pariwisata menciptakan permintaan, baik konsumsi maupun investasi yang menimbulkan kegiatan produksi barang dan jasa, sehingga langsung memunculkan permintaan (Tourism Final Demand) di pasar barang dan jasa. Sehingga Final Demand wisatawan secara tidak langsung dapat menimbulkan adanya permintaan barang modal dan bahan baku (Investment Derived Demand) untuk dapat berproduksi memenuhi permintaan wisatawan akan barang dan jasa tersebut. Dalam memenuhi permintaan wisatawan di perlukan investasi di beberapa bidang, seperti : transportasi dan komunikasi, perhotelan dan akomodasi lain, industri kerajinan dan industri produk konsumen, industri jasa, rumah makan restoran dan lain-lain Huda (2009). Dalam aspek sosial, terjadi peningkatan kerjasama masyarakat terutama di bidang ekowisata. Kegiatan sosial di masyarakat sering diadakan sejalan dengan perkembangan ekowisata (Hijriati \& Mardiana, 2015). Ekowisata adalah bentuk perencanaan wisata yang tepat untuk potensi - potensi yang dimiliki sebuah wilayah. Perkembangan pariwisata di kota tersebut lebih utama dinikmati kalangan investor berkemampuan kapital yang tinggi menurut (Mukaryanti \& Adinda Saraswati, 2005). Di sisi lain, penduduk Kota Bandung yang tinggal di pinggiran kota, tidak merasakan manfaat pariwisata secara langsung. Perkembangan pariwisata di kota tersebut lebih utama dinikmati kalangan investor berkemampuan kapital yang tinggi. Di sisi lain, penduduk Kota Bandung yang tinggal di pinggiran kota, tidak merasakan manfaat pariwisata secara langsung (Agoes, 2015).

Kabupaten Lumajang juga menyuguhkan objek wisata yang menarik dan beragam. Salah satu destinasi pariwisata yang menyuguhkan keindahan alamnya adalah wisata Hutan Bambu, yang terletak di Desa Sumber Mujur, Kecamatan Candipuro, Kabupaten Lumajang, yang terletak di Provinsi Jawa Timur. Objek wisata ini sangat cocok untuk dikunjungi, wisata Hutan Bambu ini menyuguhkan pemandangan yang terlihat indah dengan kesejukan udara di sekitarnya. Lokasi penelitian ini diambil di Desa Sumber Mujur Kecamatan Candipuro Kabupaten Lumajang, alasan pemilihan lokasi ini karena di Kabupaten Lumajang terdapat banyak berbagai macam wisata alam yang masih alami dan perlu dikembangkan untuk memajukan sektor pariwisata daerah dan sektor pariwisata merupakan salah satu penyumbang pendapatan Indonesia. Alasan lainnya adalah karena di Kecamatan Candipuro banyak 
tempat wisata yang sangat berpotensi, namun belum banyak yang dikembangkan. Serta di Kabupaten Lumajang sedang gencar-gencarnya pengembangan wisata yang menarik banyak minat pengunjung. Tujuan dari penelitian ini adalah untuk mengetahui strategi pengembangan ekowisata di Hutan Bambu Kabupaten Lumajang.

Kajian tentang Pariwisata yang dijadikan acuan dalam penelitian ini, yang pertama dilakukan oleh Satria (2009) yang berjudul "Strategi Pengembangan Ekowisata Berbasis Ekonomi Lokal Dalam Rangka Pengentasan Kemiskinan Di Wilayah Kabupaten Malang”. Kesimpulan dari penelitian ini adalah Pulau Sempu merupakan wilayah wisata yang dapat dikembangkan menjadi ekowisata yang menarik bagi wisatawan domestik dan internasional yang ingin menikmati konsep ekowisata. Pengembangan ekowisata di wilayah Pulau Sempu hendaknya dapat diselaraskan dengan kondisi sosial dan ekonomi masyarakat, serta tidak berbenturan dengan upaya konservasi yang telah dilakukkan pemerintah daerah di wilayah ini. Pengembangan ekowisata di Pulau Sempu semaksimal mungkin harus dapat melibatkan masyarakat dan pemerintah daerah secara optimal dalam setiap proses-proses didalamnya. Hal ini dilakukkan guna memberikkan ruang yang luas bagi masyarakat setempat untuk menikmati keuntungan secara ekonomi dari pengembangan ekowisata di wilayah ini. Peningkatan kerjasama perlu untuk ditingkatkan dengan institusi atau lembaga terkait, seperti agen perjalanan dan unit aktivitas mahasiswa pecinta alam, guna melahirkan ide-ide yang kreatif guna pengembangan wilayah ekowisata. Selain itu keterlibatan mereka juga diharapkan untuk memperkuat konsep ekowisata di wilayah Pulau Sempu.

Kajian kedua yaitu penelitian Devy dan Soemanto (2017) yang berjudul tentang "Pengembangan Obyek dan Daya Tarik Wisata Alam Sebagai Deerah Tujuan Wisata Di Kabupaten Karanganyar". Kesimpulan dari penelitia ini adalah strategi yang dikembangkan untuk objek Wisata Air Terjun Jumog adalah dengan membuat kebijakan-kebijakan yang telah direncanakan oleh BUMDES Berjo dan didukung oleh Pemerintah Desa, Pemerintah Daerah serta para pelaku wisata di kawasan tersebut.

Kajian ketiga adalah Penelitian (Huda,2014) dengan hasil penelitian tersebut mengatakan bahwa berdasarkan hasil penelitian maka dapat diketahui bahwa potensi wisata di Kabupaten Lombok Utara sangatlah menarik kunjungan wisatawan nusantara maupun mancanegara, hal ini terlihat dari jumlah kunjungan wisatawan nusantara yang terus meningkat dari tahun ke tahun dari lima Kecamatan yang ada di Kabupaten Lombok Utara.

Kajian penelitian keempat adalah penelitian dari (Soegiyanto dan Hadi, 2015) berisi tentang pengembangan potensi ekowisata di Kabupaten Bima, yang menunjukkan bahwa arahan strategi pengembangan ekowisata dan pengelolaannya di kabupaten Bima dapat disimpulkan menjadi tiga strategi antara lain sebagai berikut: untuk mencapai suatu pertumbuhan ekonomi dan untuk menyejahterakan masyarakat melalui berbagai ragam kegiatan pariwisata, untuk melengkapi dan memperbaiki infrastruktur, fasilitas-fasilitas sarana dan prasarana ekowisata serta untuk meningkatkan sumber daya manusia, untuk memajukan dan mengembangkan ekowisata yang berwawasan 
lingkungan dengan tetap memegang pedoman pada prinsip pengelolaan dan konservasi.

Kajian penelitian kelima adalah (Permatasi,2017) Menjelaskan tentang pengembangan ekowisata mangrove Kota Probolinggo, dari hasil penelitian ini menunjukkan bahwa adanya pengembangan yang terkonsep dari hutan bakau di Bee Jay Bakau Resort Probolinggo yang menjadikan ekowisata mangrove dan konservasi mangrove.

Perbedaan penelitian Satria (2009) dengan penelitian ini adalah penelitian. Satria (2009) bertujunn untuk pengentasan kemiskinan di wilayah Kabpaten Malang, sedangkan penelitian yang sekrang untuk pemanfaatan peluang usaha di kawasan wisata Hutan Bambu di Kabupaten Lumajang. Penelitian Devy dan Soemanto (2017) dilakukan untuk mengembangkan obyek dan daya tarik wisata di Kabupaten Karanganyar sedangkan penelitian ini dilakukan untuk mengembangkan strategi ekowisata di Hutan Bambu Kabupaten Lumajang. Persamaan penelitian (Huda, 2014), (Soegiyanto dan Hadi, 2015), (Permatasari, 2017) sama-sama bertujuan untuk mengembangkan potensi ekowisata di suatu daerah melalui strategi-strategi yang dibuat.

Menurut Kodyat dalam Oktaviana (2016) mendifinisikan ekowisata sebagai suatu kegiatan perjalanan wisata yang bertanggung jawab di daerah yang masih alami atau daerah-daerah yang dikelola dengan kaidah alam dimana tujuannya selain untuk menikmati keindahannya juga melibatkan unsur pendidikan, pemahaman dan dukungan terhadap usaha-usaha konservasi alam serta peningkatan pendapatan masyarakat setempat sekitar daerah tujuan ekowisata. Muniah (2016) menjelaskan tentang banyak nilainilai positif yang ditawarkan dalam konsep ekowisata, namun model ini masih menyisakan kritik dan persoalan terhadap pelaksanaannya.

Dampak negatif dari pariwisata terhadap kerusakan lingkungan, meski konsep kerusakan ecotourism mengedepankan isu konservasi di dalamnya, namun tidak dapat dipungkiri bahwa pelanggarab terhadap hal tersebut masih saja ditemui dilapangan. Hal ini selain disebabkan karena rendahnya pengetahuan dan kesadaran masyarakat sekitar dan turis tentang konsep ekowisata, juga disebabkan karena lemahnya manajemen dan peran pemerintah dalam konservasi dan tindakan yang tegas dalam mengatur masalah kerusakan lingkungan.

Dalam pengembangan wilayah ekowisata seringkali melupakan partisipasi masyarakat sebagai stakeholder penting dalam pengembangan wilayah atau kawasan wisata. Masyarakat sekitar seringkali hanya sebagai obyek atau penonton, tanpa mampu terlibat secara aktif dalam setiap prosesproses ekonomi didalamnya. Pengeolaan yang salah. Persepsi dan pengelolaan yang salah dari konsep ekowisata seringkali terjadi di beberapa wilayah di Indonesia. Hal ini selain disebabkan karena pemahaman yang rendah dari konsep ekowisata juga disebabkan karena lemahnya peran dan pengawasan pemerintah untuk mengembangkan wilayah wisata secara baik.

Tujuan penelitian ini adalah untuk mengetahui strategi pengembangan ekowisata hutan bamboo di Kabuaten Lumajang serta diharapkan dapat memberikan manfaat bagi banyak kalangan. Tujuan dasar pembuatan ekowisata Hutan Bambu sebagai objek wisata karena untuk menciptakan 
strategi pengembangan ekowisata yang berbasis pada lingkungan dengan mengutamakan aspek konservasi alam dalam bentuk wisata Hutan Bambu. Hal ini bertujuan agar wisata alam Hutan Bambu di Kabupaten Lumajang lebih terkenal sampai keluar Kabupaten Lumajang. Ekowisata tersebut berlokasi di dataran tinggi dan di pedesaaan yang dimana masyarakat sekitarnya masih sederhana atau tradisional, hal ini bisa dijadikan sebagai daya tarik tersendiri. Tetapi lokasi tersebut hanya memiliki satu akses jalan yang cukup memadai untuk menuju ke Hutan Bambu. Untuk jaringan listrik sudah tersedia, begitu juga dengan jaringan seluler sudah tersedia, namun tidak semua jaringan seluler tersedia.

\section{METODE PENELITIAN}

Penelitian ini menggunakan populasi pada seluruh masyarakat yang ada di dalam wisata Hutan Bambu radius $3 \mathrm{~km}$. Penentuan sampel pada penelitian ini menggunakan teknik purpose sampling, yaitu teknik sampling yang memberikan peluang yang sama bagi setiap unsur populasi untuk dipilih menjadi sampel, atau pengambilan sampel secara random atau acak. Penentuan sampel pada penelitian ini terdiri dari pengunjung, pedagang atau penjual, dan pihak pengelola wisata Hutan Bambu yang berperan sebagai narasumber dan diambil masing-masing satu narasumber.

Penelitian ini menggunakan teknik pengumpulan data dengan cara observasi dan wawancara yang dilakukan di wisata Hutan Bambu Kabupaten Lumajang. Wawancara dilakukan beberapa kali sesuai dengan keputusan peneliti yang berkaitan dengan kejelasan dan kemantapan masalah yang diteliti. Observasi yang bertujuan untuk mengamati secara langsung kegiatan dan aktivitas setiap pengunjung yang dilakukan di ekowisata Hutan Bambu Kabupaten Lumajang. Observasi dilakukan pada hari biasa dan pada hari libur di Hutan Bambu Kabupaten Lumajang.

Peneliti mendapatkan banyak data dan informasi yang dapat digunakan untuk mendukung penelitian. Teknik analisis data pada penelitian ini menggunakan alat analisis SWOT (Strong, Weakness, Opportunity, dan Threat) dan alat analisisi deskriptif dan kualitatif. Alat yang dipakai untuk menyusun faktor-faktor strategis perusahaan adalah matriks SWOT matri kini dapat menggambarkan secara jelas bagaimana peluang dan ancaman eksternal yang dihadapi perusahaan dapat disesuaikan dengan kekuatan dan kelemahan yang dimilikinya. Matriks SWOT membantu menyusun berbagai alternatif strategi berdasarkan kombinasi antara factor kekuatan, peluang, dan ancaman melalui pengembangan empat tipe strategi, yaitu: SO (streght opportunities), WO (weaknesess-threats) ST (strengths-threats), dan WT (weaknesses thrats).Seperti tampak dalam gambar di bawah ini: Proses pengambilan keputusan strategi selalu berkaitn denan pengembangan, strategi. Model ini yang paing popular untuk menganalisis situasi yaitu analisis SWOT Rangkuti (2008).

\section{HASIL DAN PEMBAHASAN}

Wisata Hutan Bambu di Kabupaten Lumajang merupakan lokasi wisata alam yang sebelumnya hanya lokasi hutan bambu dengan luas hanya 5 hektar, 
sehingga saat ini sudah berkembang keadaannya menjadi 14 hektar. Kemudian pada tahun 1970-an oleh sekelompok masyarakat dengan kesadaran pribadi mulai melakukan upaya untuk pelestarian dan sosialisasi pada para masyarakat setempat sehingga lama-lama mulai dikembangkan menjadi lokasi wisata, sehingga menjadi lokasi wisata yang memiliki daya tarik tersendiri yakni ada banyak pohon bambu yang usianya puluhan tahun dan udaranya yang sejuk sehingga suasana tenang dapat dinikmati karena jauh dari keramaian kota serta polusi.

Wisata hutan bambu juga memiliki sumber air yaitu Sumber Delling yang digunakan oleh masyarakat sekitar untuk menjadi sumber utama pengairan persawahan di kawasan tersebut. Wisata hutan bambu juga sebagai habitat satwa seperti kalong (kelelawar besar), kera, elang jawa, dan jeis burung lainnya. Selain itu, hutan bambu merupakan salah satu sumber genetik juga dari berbagai tanaman-tanaman lainnya ada 22 jeis tanaman selain bambu. Jenis bambu yang ada di wisata hutan bambu ada 18 (delapan belas) jenis bambu antara lain bambu apus, bambu jajang, bambu petung hijau, bambu petung hitam, bambu rampal, bambu wulung, bambu rampal kuning, bambu ampel hijau, bambu hias Cina, bambu hias bergaris putih, bambu ampel kuning, bambu hijau bergaris kuning, bambu hias batang kuning, bambu hias mini, bambu ori, bambu nagin, bambu tutup, dan bambu tutul. Keadaan yang ada, pada umumnya ekowisata Hutan Bambu memiliki kekayaan alam yang sangat jarang ditemui di Kabupaten Lumajang yang sangat menarik untuk dapat dikembangkan lagi. Beberapa potensi kenapa lokasi ini sangat relatif terjaga keindahan alamnya, yaitu: menurut pihak pengelola Wisata Hutan Bambu. Para narasumber dalam penelitian ini terdiri dari pihak pengelola hutan bamboo yang memiliki pekerjaan lainnya selain mengelola hutan bamboo yaitu sebagai petani, dan para pedagang juga berprofesi sebagai petani, dan nrasumber terakhir adalah wisatawan atau pengunjung yang berprofesi sebagai wiraswasta yang sedang berkunjung dan bersedia menjadi narasumber. Menurut para pengunjung atau wisatawan "untuk dapat menikmati apa yang tersedia dan disuguhkan di Wisata Hutan Bambu harus melalui akses jalan yang hanya tersedia dan jalannya tidak mudah dilalui karena perlu adanya perbaikan, yang dimana dari pusat kota Kabupaten Lumajang untuk bisa tiba di lokasi Wisata Hutan Bambu membutuhkan waktu sekitar 35 menit s/d 1 jam perjalanan tergantung pengendara, bisa ditempuh dengan kendaraan roda 2 atau roda 4. Jaraknya $30 \mathrm{~km}$ dari pusat kota Kabupaten Lumajang".

Menurut pihak pengelola kawasan wisata Hutan Bambu 'masyarakat. Untuk jaringan listrik di lokasi wisata maupun lokasi sekitar kawasan wisata sangat memadai. Jaringan seluler juga sudah tersedia dan bisa terakses dengan baik. Dengan adanya flora dan fauna di Hutan Bambu ekowisata ini juga cocok dijadikan sebagai wisata edukasi dengan berwawasan lingkungan. pengunjung yang terdiri dari anak-anak, remaja, dn orang tua mengunjungi lokasi untuk diperkenalkan dengan berbagai macam jenis tanaman dan manfaatnya.

Matrik faktor strategi ekternal (EFAS) dan matrik faktor strategi internal (IFAS) Hutan Bambu, merupakan faktor eksternal dan internal Hutan Bmabu yang dimana hasil dari masing-masing matrik dapat digunakan sebagai perbandingan dengan wisata lainnya. Matrik faktor strategi eksternal Hutan 
Bmabu dapat dilihat pada Tabel berikut. Orang yang melakukan perjalanan tidak mencari nafkah di tempat yang dikunjungi. Menurut Antari (2013) Pariwisata adalah perjalanan yang dilakukan manusia ke daerah yang bukan merupakan tempat tinggalnya dalam waktu paling tidak satu malam dengan tujuan perjalananannya bukan untuk mencari nafkah, pendapatan atau untuk penghidupan di tempat tujuan.

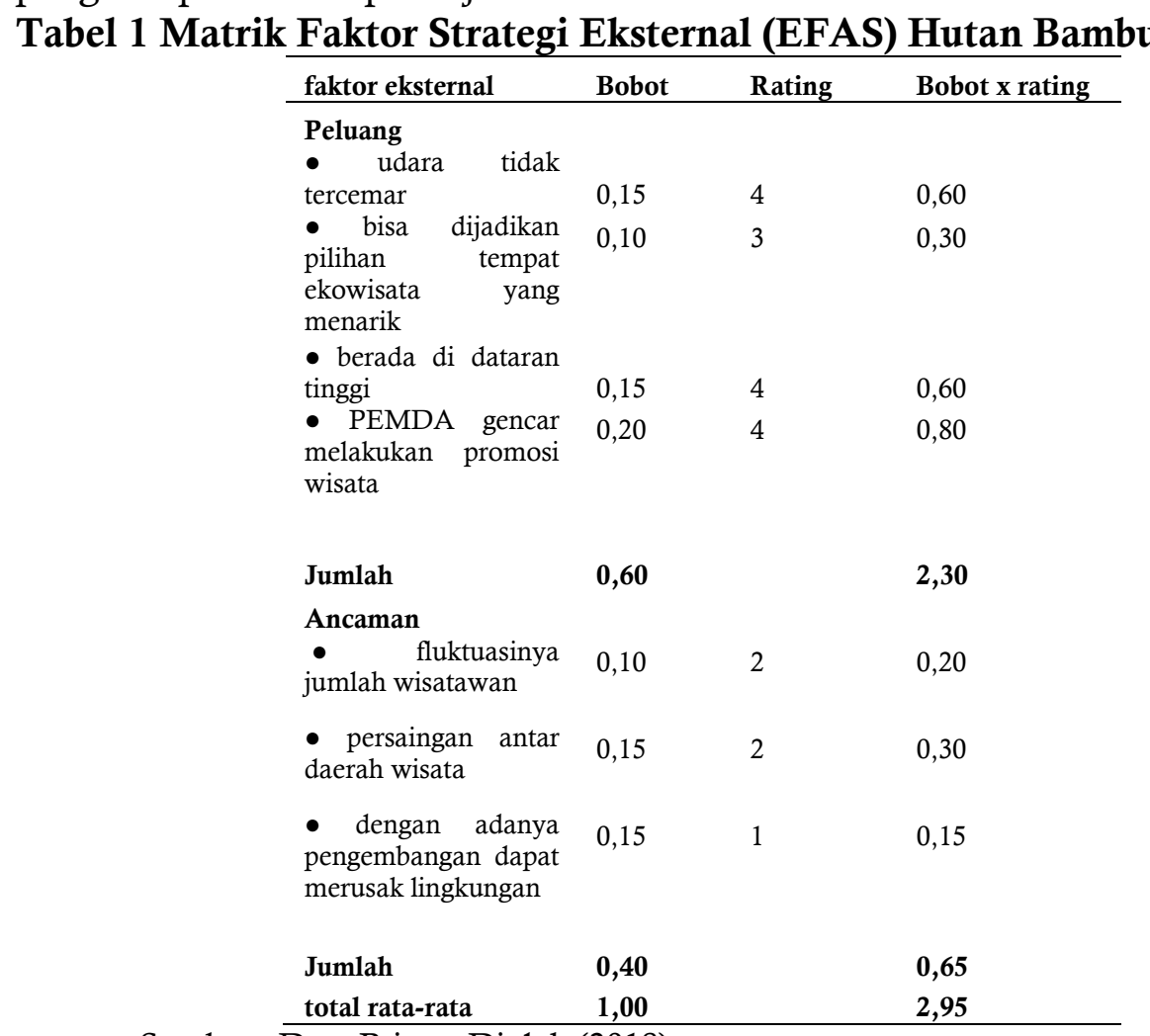

Sumber : Data Primer Diolah (2018)

Pada Tabel 1 dapat dilihat faktor strategis eksternal yang berupa peluang Hutan Bambu dalam pengembangannya memiliki skor $(2,30)$. Peluang yang dapat diandalkan adalah pemerintah daerah setempat sedang gencar-gencarnya melakukan promosi tentang wisata yang terdapat di daerah tersebut dengan skor tertinggi $(0,80)$; lokasi yang berada di dataran tinggi memiliki skor $(0,60)$; dan udara yang tidak tercemar di Hutan Bambu memiliki skor $(0,60)$; sedangkan untuk dapat dijadikannya Hutan Bambu menjadi pilihan tempat wisata yang menarik memiliki skor $(0,30)$.

Faktor strategis eksternal yang berupa ancaman pada Tabel diatas, memiliki skor $(0,65)$. Skor tertinggi ada pada persaingan antar daerah wisata dengan skor $(0,30)$; fluktuasi jumlah para wisatawan yang berkunjung di ekowisata Hutan Bambu memilik skor $(0,20)$; dengan adanya pengembangan pada ekowisata Hutan Bambu akan dapat menyebabkan rusaknya lingkungan memiliki skor $(0,15)$. Hal-hal seperti ini sangat menjadi ancaman dalam upaya pengembangan ekowisata tersebut, karena dilihat dari peluang yang dimiliki Hutan Bambu merupakan modal utama untuk pengembangannya. Dari data pada Tabel 1 jumlah total rata-rata EFAS hutan bambu memiliki skor $(3,95)$. 
Tabel 2 Faktor Strategi Internal Hutan Bambu

\begin{tabular}{|c|c|c|c|}
\hline faktor internal & Bobot & Rating & bobot $\mathrm{x}$ rating \\
\hline \multicolumn{4}{|l|}{ Kekuatan } \\
\hline - daerah yang strategis & 0,10 & 3 & 0,30 \\
\hline $\begin{array}{l}\text { - kehidupan masyarakat } \\
\text { pedesaan }\end{array}$ & 0,15 & 3 & 0,45 \\
\hline $\begin{array}{l}\text { - adanya tim } \\
\text { pengembangan ekowisata }\end{array}$ & 0,12 & 4 & 0,48 \\
\hline $\begin{array}{lr}\text { - } & \text { dukungan } \\
\text { pengembangan } & \text { dari } \\
\text { masyarakat } & \end{array}$ & 0,15 & 4 & 0,60 \\
\hline Jumlah & 0,52 & & 1,83 \\
\hline $\begin{array}{l}\text { Kelemahan } \\
\text { - infrastruktur yang tidak } \\
\text { memadai }\end{array}$ & 0,05 & 1 & 0,05 \\
\hline $\begin{array}{l}\text { - kurangnya dana dan } \\
\text { promosi }\end{array}$ & 0,10 & 2 & 0,20 \\
\hline $\begin{array}{l}\text { - jauhnya jarak dari pusat } \\
\text { kota }\end{array}$ & 0,06 & 1 & 0,06 \\
\hline $\begin{array}{l}\text { - tidak semua jaringan } \\
\text { seluler tersedia }\end{array}$ & 0,06 & 1 & 0,06 \\
\hline $\begin{array}{l}\text { - belum adanya hotel, } \\
\text { home stay atau } \\
\text { penginapan, warung hanya } \\
\text { asal-asalan }\end{array}$ & 0,10 & 2 & 0,20 \\
\hline $\begin{array}{l}\text { - kurangnya sarana } \\
\text { penunjang atraksi wisata }\end{array}$ & 0,05 & 2 & 0,10 \\
\hline $\begin{array}{l}\text { - kesadaran yang kurang } \\
\text { dalam menjaga objek } \\
\text { wisata }\end{array}$ & 0,06 & 1 & 0,06 \\
\hline $\begin{array}{l}\text { Jumlah } \\
\text { total rata-rata }\end{array}$ & $\begin{array}{l}0,48 \\
1,00\end{array}$ & & $\begin{array}{l}0,73 \\
2,56\end{array}$ \\
\hline
\end{tabular}

Sumber : Data Primer Diolah (2018)

Tingginya nilai dukungan pengembangan dari masyarakat sekitar akan dapat mengembangkan ekowisata Hutan Bambu di masa mendatang dan nilai ini menunjukkan bagaimana ekowisata tersebut bereaksi dengan faktor-faktor strategi internalnya, dapat juga digunakan sebagai perbandingan dengan ekowisata lainnya. Nilai dukungan pengembangan dari masyarakat sekitar akan dapat mengembangkan ekowisata Hutan Bambu di masa mendatang dan nilai ini menunjukkan bagaimana ekowisata tersebut bereaksi dengan faktorfaktor strategi internalnya, dapat juga digunakan sebagai perbandingan dengan ekowisata lainnya.

Dari data pada Tabel 2, terlihat faktor strategis internal yang merupakan kekuatan memiliki skor $(1,83)$. Diamati dari berbagai faktor yang terdapat di dalamnya, berupa dukungan pengembangan dari masyarakat sekitar untuk mengembangkan ekowisata Hutan Bambu memiliki skor tertinggi $(0,60)$; adanya tim pengembangan ekowisata sehingga Hutan Bambu dapat dikembangkan untuk kedepannya memiliki skor $(0,48)$; daerah ekowisata 
Hutan Bambu yang strategis menjadikan dorongan untuk berkembangnya ekowisata tersebut memiliki skor $(0,30)$; kedihupan masyarakat sekitar Hutan Bambu merupakan masyarakat pedesaan yang masih kental dengan sederhana memiliki skor $(0,45)$.

Tingginya nilai dukungan pengembangan dari masyarakat sekitar akan dapat mengembangkan ekowisata Hutan Bambu di masa mendatang. Sedangkan faktor strategi internal yang merupakan kelemahan dapat dilihat pada Tabel 2, memiliki skor $(0,73)$. Yang di dalamnya berupa infrastruktur yang ada di Hutan Bambu yang tidak memadai memiliki skor $(0,05)$; kurangnya dana dan promosi yang ada pada ekowisata tersebut memiliki skor $(0,20)$; jauhnya jarak Hutan Bambu dari pusat kota memiliki skor $(0,06)$; tidak semua jaringan tersedia di kawasan ekowisata Hutan Bambu memiliki skor $(0,06)$; belum adanya hotel, home stay atau penginapan, serta warung yang hanya asal-asalan yang ada di kawasan ekowisata memiliki skor $(0,20)$; kurangnya sarana penunjang atraksi wisata yang ada mrmiliki skor $(0,10)$; dan kesadaran yang kurang dalam menjaga objek ekowisata tersebut memiliki skor $(0,06)$.

Jumlah total rata-rata IFAS Hutan Bambu memiliki skor $(2,56)$ yang dapat dilihat pada Tabel 2. Nilai ini menunjukkan bagaimana ekowisata tersebut bereaksi cukup baik terhadap pengembangan ekowisata hutan bamboo. Adanya faktor-faktor strategi internalnya, dapat juga digunakan sebagai perbandingan dengan ekowisata lainnya. Data di ambil berdasarkan hasil dari wawancara dengan para narasumber yang terdiri dari pengelola hutan bamboo, pedagang, dan pengunjung.

\section{Tabel 3 Hasil Matrik SWOT Hutan Bambu}

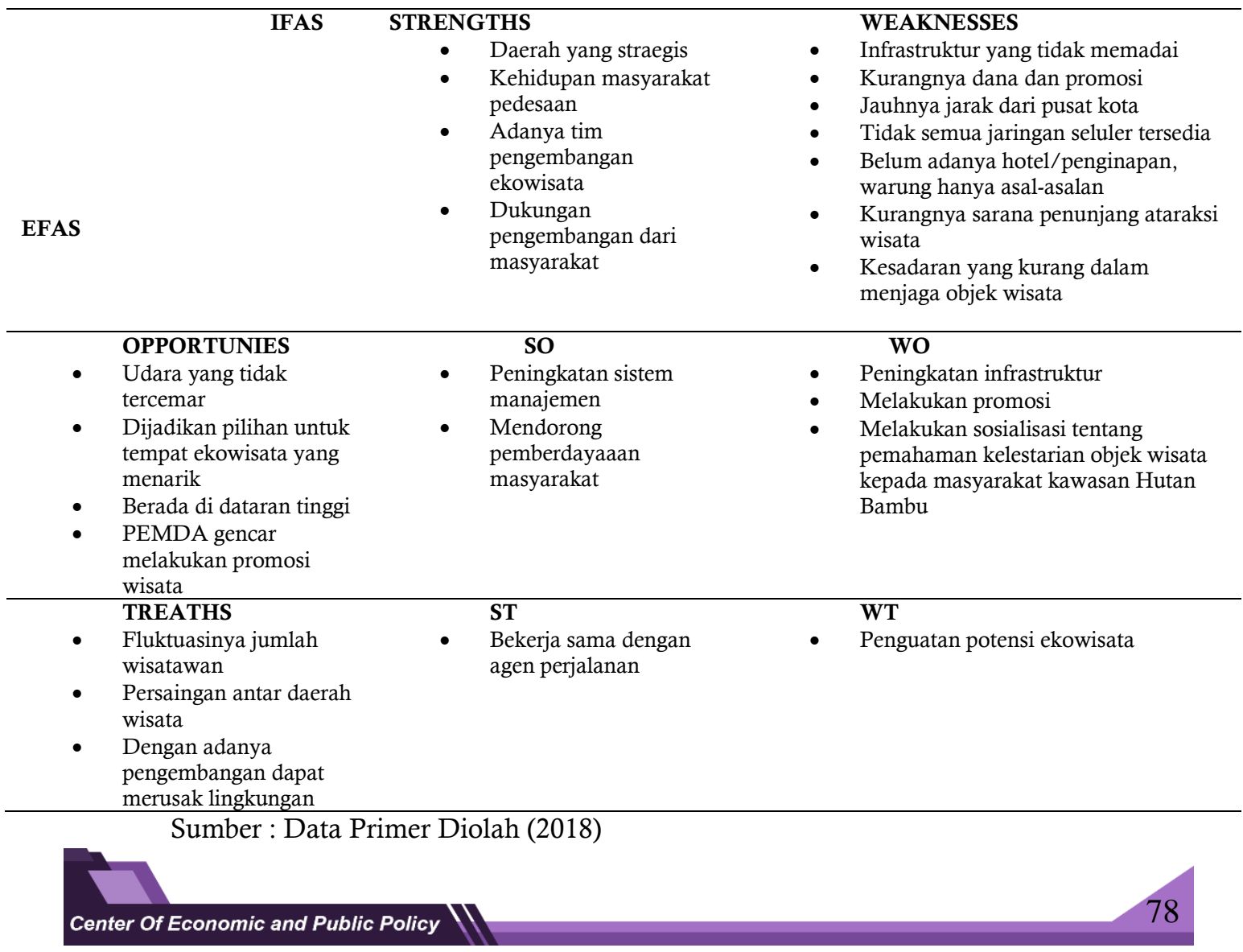


Pada Tabel 3 dapat dilihat dengan adanya potensi-potensi yang berada di Hutan Bambu, terdapat beberapa yang harus dilakukan oleh pengambil kebijakan yaitu pihak yang mengelola, untuk mengembangkan ekowisata Hutan Bambu: Penguatan dan peningkatan sistem manajemen kepariwisataan. Dengan sistem manajemen yang baik dapat dijadikan kontrol dalam pengembanagn ekowisata, dimana sistem manajemen yang ada sebenarnya sudah terstruktur dan mengerjakan tugasnya dengan baik, namun untuk mengembangkan lokasi wisata ini diperlukan sitem manajemen yang lebih baik lagi, karena dalam pengembangannya diperlukan sebuah kontrol yang lebih banyak, seperti pengawasaan proses pengembangannya agar tetap ke arah konsep ekowisata yang ada di Hutan Bambu.

Adanya suatu konsep ekowisata, seharusnya di Hutan Bambu dapat menguatkan potensi wisata alam yang dapat menarik pengunjung atau para wisatawan dari berbagai daerah. Pemerintah juga harus ikut serta andil dalam mengembangkannya, agar dapat meningkatkan nilai ekonomis daerah ini guna menguatkan ekonomi masyarakat sekitar. Tetapi dengan adanya pengembangan ekowisata ini dapat juga mengakibatkan kerusakan lingkungan, sehingga diperlukan upaya untuk mengatasi dampak negatif ini. Salah satunya dengan mengarahkan ekowisata Hutan Bambu ke arah konsep ekowisata yang ada disana, sehingga pengembangannya searah dengan konservasi lingkungan serta berdampak baik bagi pengembangan ekonomi lokal.

Pengembangan ekonomi lokal ini dilakukan bukan hanya untuk keberlanjutan konservasi, tetapi untuk kesejahteraan masyarakat sekitar. Untuk mengembangkan ekonomi lokal maka diperlukan pemahaman yang tepat ke masyarakat dan pemerintah lokal, dimana nantinya mereka (masyarakat dan pemerintah lokal) akan lebih aktif lagi dalam berperan mengembangkan lokasi ini. Seperti dengan mengembangkan unit-unit ekonomi (BUMDES - Badan Usaha Milik Desa) dan koperasi untuk mendukung aktivitas dan kebutuhan wisatawan, mulai dari mengembangkan usaha warung makanan, souvenir, penginapan, hingga pemandu wisata.

Pihak pengelola harus bekerja sama dengan agen perjalanan (pemandu wisata). Pemandu wisata menjadi hubungan erat dengan berkembangnya ekowisata Hutan Bambu, sehingga nantinya akan mudah dalam mengembangkan lokasi tersebut, partisipasi agen perjalanan harus tetap dikintrol. Bukan hanya itu, kerjasama dengan agen perjalanan harus terdapat kesepakatan tentang konsep ekowisata yang sesua dengan akan dikembangkan di Hutan Bambu serta pemandu wisata juga harus tetap memberdayakan masyarakat lokal (masyarakat sekitar).

Melakukan promosi yang gencar. Dengan melakukan promosi yang gencar akan semakin baik juga untuk pengembangan lokasi wisata Hutan Bambu, karena hal ini dapat memberikan gambaran wisata yang baik di lokasi Hutan Bambu. Dimana untuk saat ini Kabupaten Lumajang juga sedang gencar-gencarnya dalam mengenalkan wisatanya, jadi pemerintah juga harus berperan dalam hal ini, serta dengan kerjasama yang dilakukan bersama agen perjalanan juga dapat memperkenalkan wisata Hutan Bambu melalui internet maupun promosi yang biasa agen perjalanan lakukan. 
Mendukung partisipasi aktivitas Pecinta Alam untuk melakukan program konservasi. Peningkatkan dan pengawasan upaya konservasi bukan hanya dapat dilakukan oleh pihak-pihak yang berperan langsung dalam Hutan Bambu namun juga dapat dikoordinasikan dengan organisasi-organisasi Pecinta Alam dari berbagai wilayah. Karena organisasi Pecinta Alam selalu memiliki aktivitas yang ramah dengan lingkungan, seperti menjaga kebersihan serta melakukan pengawasan dan pemanduan terhadap pengunjung wisata Hutan Bambu.

Meningkatkan infrastruktur seperti akses jalan menuju lokasi Hutan Bambu, infrastruktur penunjang atraksi wisata. Apalagi pihak pemerintah sedang gencar mempromosikan wisata daerahnya, sehingga untuk masalah dana pengembangan maupun promosi wisata seharusnya dapat di atasi, karena dalam pengembangannya membutuhkan dana yang tidak kecil. Mendorong pemberdayaan masyarakat sekitar wisata, namun masyarakat juga jangan di dilepaskan sendirian dalam mengelola semuanya. Karena masalah kualitas Sumber Daya Manusia (SDM) yang diakibatkan dari tidak meratanya pendidikan yang diperoleh di Indonesia, sehingga perlu melibatkan pemerintah lokal dan juga beberapa pihak yang bersangkutan dalam hal pengembangan ekowisata. Ditambah dengan ikut sertanya beberapa generasi masyarakat yang akan menjadikan pengelolaan menjadi berkelanjutan.

\section{KESIMPULAN}

Strategi-strategi pengembangan Ekowisata Hutan Bambu sebagai berikut: Peningkatan sistem manajemen, sistem manajemen yang baik bisa dijadikan control dalam pengembangan ekowisata; Mendorong pemberdayaan masyarakat sekitar wisata; Bekerja sama dengan pihak agen perjalanan. Pihak pengelola wisata Hutan Bambu akan mudah dalam mengembangkan lokasi tersebut dengan adanya partisipasi dari pihak agen perjalanan; Penguatan potensi, mengarahkan ekowisata hutan bambu kea rah konsep ekowisata yang ada disana, sehingga pengembangannya searah dengan konservasi lingkungan serta berdampak baik bagi pengembangan ekonomi masyarakat sekitar; Peningkatan infrastruktur, seperti akses jalan menuju lokasi hutan bambu supaya memudahkan para wisatawan untuk berkunjung; Melakukan promosi, dengan melakukan promosi yang gencar akan semakin baik juga pengembangan lokasi wisata hutan bamboo, karena hal ini dapat memberikan gambaran wisata yang baik di lokasi hutan bamboo.

\section{DAFTAR PUSTAKA}

Agoes, A. (2015). Pengembangan Produk Pariwisata Perdesaan Di Kampung Dago Pojok Bandung. 12(1), 73-99. https://doi.org/10.17509/jurel.v12i1.1049

Ananda, A. D., \& Susilowati, D. (2017). Pengembangan Usaha Mikro Kecil dan menengah (UMKM) Berbasis Industri Kreatif di Kota Malang. Jurnal Ilmiah Ekonomi, 10, 120-142. 
Antari, N. L. S. (2013). Peran Industri Pariwisata terhadap Penerimaan Pendapatan Asli Daerah Kabupaten Gianyar. Jurnal Perhotelan Dan Pariwisata, 3(1), 260-280.

Boedirachminarni, A. (2017). Analisis Kepuasan Pengunjung Ekowisata Kabupaten Malang. Junal Ekonomi Pembangunan, 15(01).

Choridatul, B., Wahyu, H. R., \& Sudarti. (2018). Strategi Pengembangan Potensi Pariwisata di Pantai Duta Kabupaten Probolinggo. Jurnal Ilmu Ekonomi, 2, 95-103.

Di, K., \& Denpasar, K. (2017). Perencanaan strategi prioritas kesempatan kerja di kota denpasar. 1, 499-513.

Hijriati, E., \& Mardiana, R. (2015). Pengaruh Ekowisata Berbasis Masyarakat Terhadap Perubahan Kondisi Ekologi, Sosial Dan Ekonomi Di Kampung Batusuhunan, Sukabumi. Sodality: Jurnal Sosiologi Pedesaan, 2(3), 146-159. https://doi.org/10.22500/sodality.v2i3.9422

Huda, S. (2009). Analisis Penerimaan Devisa Sektor Pariwisata dan Faktor-Faktor Yang Mempengaruhi di Provinsi Jawa Timur. Jurnal Aplikasi Manajemen, 7(1), 34-41.

Huda, S. (2014). Analisis potensi sektor pariwisata di kabupaten lombok utara skripsi.

Ihsan, Soegiyanto, H., \& Hadi, P. (2015). Pengembangan Potensi Ekowisata di Kabupaten Bima. Jurnal GeoEco, 1(2), 195-206.

Kumala, M., Soelistyo, A., \& Nuraini, I. (2017). Analisis potensi sektor pariwisata sebagai sektor unggulan di wilayah jawa timur. Ilmu Ekonomi, 1(4), 474-481.

Mukaryanti, Mps., \& Adinda Saraswati, S. (2005). Pengembangan Ekowisata Sebagai Pendekatan Pengelolaan Sumber Daya Pesisir Berkelanjutan Kabupaten Pemalang. Jurnal Teknik Lingkungan, 6(3), 391396.

Muniah. (2016). Strategi Pengembangan Ekowisata Berbasis Ekonomi Lokal Dalam Rangka Program Pengentasan Kemiskinan Di Wilayah Karimun Jawa. Jurnal Ilmu-Ilmu Pertanian, Agrika, 10(1).

Permatasi, P. I. (2017). Pengembangan Fungsi Ekowisata Mangrove “ Bee Jay Bakau Resort " Kota Probolinggo bagi Pengunjung. Universitas Airlangga.

Rangkuti, F. (2008). The Power of Brands (Gramedia P). Jakarta. 